\title{
RARE CASE OF INVASIVE LOBULAR BREAST CANCER METASTASIS TO THE ENDOMETRIUM
}

\author{
DAMIR DANOLIĆ ${ }^{1}$, LUKA MARCELIĆ ${ }^{1}$, ILIJA ALVIR ${ }^{1}$, IVICA MAMIĆ1, \\ LUCIJA ŠUŠNJAR ${ }^{1}$, ZRINKA RENDIĆ-MIOČEVIĆ ${ }^{2}$ and MARIO PULJIZ ${ }^{1}$ \\ ${ }^{1}$ Department of Gynecologic Oncology, University Hospital for Tumors, \\ Sestre milosrdnice University Hospital Center, Zagreb, Croatia; \\ ${ }^{2}$ Division of Oncology and Radiotherapy, University Hospital for Tumors, \\ Sestre milosrdnice University Hospital Center, Zagreb, Croatia;
}

\begin{abstract}
Summary
Metastases to the female genital tract from extra-genital primary cancers are uncommon and usually occur during widespread metastatic disease. Breast cancers are the most frequent primaries, predominantly the lobular type. Here, we report a case of a 55-year-old woman with breast cancer endometrial metastasis who presented with postmenopausal vaginal bleeding. We highlight the importance of endometrial sampling to confirm the diagnosis and distinguish primary from metastatic cancer of the endometrium since the treatment and prognosis of these conditions are entirely different.
\end{abstract}

KEYWORDS: breast cancer, metastasis, endometrium, vaginal bleeding

\section{INTRODUCTION}

Breast cancer is the most common malignancy in women worldwide (1). Approximately $6 \%$ of breast cancer patients initially present with metastases, and 30\% will develop metastasis after definitive treatment (2). The most often breast cancer metastasis sites are lung, liver, bone, and brain, while primary metastases to the female genital tract are extremely rare $(3,4)$. When metastases to the genital tract are present, ovaries are the most often involved due to peritoneal spread, accounting for $75.8 \%$ of metastasis to genital organs (2). Breast cancer metastasis to the uterus is an exceedingly rare clinical finding and presents a significant diagnostic challenge $(2,5)$. Herein, we report a case of a breast cancer patient who presented

Corresponding author: Luka Marcelić, Department of Gynecologic Oncology, University Hospital for Tumors, Sestre milosrdnice University Hospital Center, Ilica 197, 10000 Zagreb, Croatia.

e-mail:luka.marcelic2@gmail.com with abnormal uterine bleeding and was subsequently diagnosed with breast cancer metastasis to the endometrium.

\section{CASE REPORT}

A 55-year-old woman presented to her primary gynecologist with postmenopausal vaginal bleeding. She was diagnosed with breast cancer two years ago and underwent a segmental mastectomy with sentinel lymph node dissection. Pathology revealed grade 3 invasive lobular carcinoma measuring $2.2 \mathrm{~cm}, \mathrm{ER} / \mathrm{PR}+$, and Her-2 negative, Ki-67 was $26.2 \%$. Epithelial cadherin (E-cadherin) had an aberrant expression. Microscopic examination of sentinel lymph nodes came positive for metastasis. After surgery, she received adjuvant chemotherapy (4 cycles of cyclophosphamide and adriamycin followed by 12 cycles of paclitaxel) and radiation therapy (total dose of 50 Gy/25 fractions followed by a boost dose of 12.5 
Gy/5 fractions). Since the tumor showed strongly positive hormone receptor expression, she was under endocrine therapy with anastrozole.

Approximately two years after her initial diagnosis, the patient experienced postmenopausal uterine bleeding. Vaginal bleeding was mild and self-limited, while speculum examination did not reveal any signs of vaginal bleeding. Due to postmenopausal vaginal bleeding, an endometrial biopsy was performed. Histopathology with immunohistochemical staining confirmed metastases to the endometrium, consistent with her known history of invasive lobular breast carcinoma. She was referred to our department for evaluation and further management. PET/CT scan was administered and did not reveal areas of increased uptake in either the ovaries or the uterus. However, the patient had diffuse osseous metastases. During a multidisciplinary team conference, the patient was discussed and decided to undergo systemic therapy with pablociclib and fulvestrant due to hormone-receptor-positive advanced breast cancer, which has progressed on prior endocrine therapy. The patient is under the sixth cycle of therapy without disease progression signs on PET/CT scan.

\section{DISCUSSION}

Metastases from extra-genital cancers to the genital tract are extremely rare, with breast and colon being the most common origins of metastases $(5,6)$. Piura et al. concluded that $56 \%$ of primary extra-genital cancers that metastasize to the uterus originate from the breast. However, when the genital tract is affected, the ovaries are the most common site of metastases $(5,7)$. One study reported that, among 149 metastatic tumors to the female genital tract from extra-genital cancers, the ovary and vagina were the most frequent metastases $(75.8 \%$ and $13.4 \%)$, and only $8.1 \%$ were to the uterus (8). Mazur et al. analyzed the localization of the metastases in the uterus: $3.8 \%$ of cases involved the endometrium, $63,5 \%$ of cases involved myometrium, and $32.7 \%$ of cases both the myometrium and endometrium(9).

Although rarer than ductal type, invasive lobular cancer is the most frequent histologic type that metastasizes the female genital tract. These differences between infiltrating lobular carcinoma and ductal carcinoma could be because of the small size of lobular cancer cells and loss of cell adhesion molecule E-cadherin expression $(3,10)$. E-cadherin is a transmembrane glycoprotein that mediates intercellular adhesion and is engaged in epithelial cell-to-cell adhesion. Numerous studies have linked aberrant expression of E-cadherin, as in our case report, with more invasive cancer phenotype and the development of metastases in breast cancer and other cancers (11).

Uterine metastases of extra-genital cancer pose a significant diagnostic challenge for both physicians and pathologists. It may be challenging to differentiate between uterine cancer and the uterine metastases of breast cancer. Both have similar glandular architecture, and both, in most cases, demonstrate hormone receptors' positivity. GATA3 and cytokeratin immunohistochemical staining should be used in such cases since they are sensitive markers for metastatic breast cancer $(2,12)$.

Abnormal uterine bleeding is often the first symptom when the endometrium is involved. However, if the metastases affect myometrium only, patients may often be asymptomatic $(6,10)$. It is easy to mistake the typical presentation of abnormal vaginal bleeding as a primary disease rather than the genital tract's metastatic involvement. Endometrial biopsy is crucial in distinguishing primary from metastatic cancer of the endometrium $(4,5)$. Uterine metastases from extra-genital cancers usually occur as a manifestation of advanced disease, and in the majority of cases, ovaries are also affected $(5,13)$. However, in our case, both ultrasound and PET/CT scans of ovaries were normal.

There is a lack of data regarding the best approach in uterine metastases in the context of widespread disease. Most studies suggest no foreseeable benefit from specific local treatment (e.g., surgery or radiotherapy) other than palliation of symptoms and prevention of cancer-related complications $(5,14)$. Systemic therapy is considered to be the mainstay of the treatment of such patients $(5,14,15)$.

\section{CONCLUSION}

In conclusion, this case report shows how important it is to maintain a broad differential diagnosis in patients with postmenopausal bleeding 
and breast cancer history. It is of utmost importance to determine whether the uterine tumor is metastatic or primary since treatment modalities and prognosis of these conditions are entirely different. Proper evaluation of symptoms with an endometrial biopsy is essential in identifying the underlying pathology. However, due to data paucity regarding this condition, more cases and more studies are necessary to improve our knowledge about the best treatment options for these patients.

\section{Acknowledgments}

No potential conflict of interest was reported by the authors.

\section{REFERENCES}

1. Siegel RL, Miller KD, Jemal A. Cancer statistics, 2020. CA Cancer J Clin. 2020;70(1):7-30.

2. Akhtar A, Ratra A, Puckett Y, Sheikh AB, Ronaghan CA. Synchronous Uterine Metastases from Breast Cancer: Case Study and Literature Review. Cureus [Internet]. 2017 [cited 2020 May 31];9(11). Available from: https://www.ncbi.nlm.nih.gov/pmc/articles/ PMC5766353/

3. Komeda S, Furukawa N, Kasai T, Washida A, Kobayashi $\mathrm{H}$. Uterine metastasis of lobular breast cancer during adjuvant letrozole therapy. J Obstet Gynaecol. 2013 Jan;33(1):99-101.

4. Franco-Márquez R, Torres-Gaytán AG, Narro-Martinez MA, Carrasco-Chapa A, Núñez BG, Boland-Rodriguez E. Metastasis of Breast Lobular Carcinoma to Endometrium Presenting as Recurrent Abnormal Uterine Bleeding: A Case Report and Review of Literature. Case Rep Pathol. 2019;2019:5357194. doi: $10.1155 / 2019 / 5357194$

5. Binstock A, Smith AL, Olawaiye AB. Recurrent breast carcinoma presenting as postmenopausal vaginal bleeding: A case report. Gynecol Oncol Rep. 2013 Jun 24;10:38-40.
6. Arslan D, Tural D, Tatlı AM, Akar E, Uysal M, Erdoğan G. Isolated Uterine Metastasis of Invasive Ductal Carcinoma. Case Rep Oncol Med [Internet]. 2013 [cited 2020 May 30];2013. Available from: https://www.ncbi. nlm.nih.gov/pmc/articles/PMC3612463/

7. Piura B, Yanai-Inbar I, Rabinovich A, Zalmanov S, Goldstein J. Abnormal uterine bleeding as a presenting sign of metastases to the uterine corpus, cervix and vagina in a breast cancer patient on tamoxifen therapy. Eur J Obstet Gynecol Reprod Biol. 1999 Mar;83(1):57-61.

8. Horikawa M, Mori Y, Nagai S, Tanaka S, Saito S, Okamoto T. Metastatic breast cancer to the uterine cervix mimicking a giant cervical leiomyoma. Nagoya J Med Sci. 2012 Aug;74(3-4):347-51.

9. Mazur MT, Hsueh S, Gersell DJ. Metastases to the female genital tract. Analysis of 325 cases. Cancer. 1984 May 1;53(9):1978-84.

10. Gomez M, Whitting K, Naous R. Lobular breast carcinoma metastatic to the endometrium in a patient under tamoxifen therapy: A case report. SAGE Open Med Case Rep [Internet]. 2020 Feb 16 [cited 2020 May 31];8. Available from: https://www.ncbi.nlm.nih.gov/ pmc/articles/PMC7026837/

11. Kowalski PJ, Rubin MA, Kleer CG. E-cadherin expression in primary carcinomas of the breast and its distant metastases. Breast Cancer Res. 2003;5(6):217-22.

12. Braxton DR, Cohen C, Siddiqui MT. Utility of GATA3 immunohistochemistry for diagnosis of metastatic breast carcinoma in cytology specimens. Diagnostic Cytopathology. 2015;43(4):271-7.

13. Seo SY, Shin JY, Ji YI. Metastatic uterine cancer looking as cervical fibroid in recurrent breast cancer woman: a case report. Obstet Gynecol Sci. 2017 Sep;60(5):481-4.

14. Pagani O, Senkus E, Wood W, Colleoni M, Cufer T, Kyriakides S, et al. International guidelines for management of metastatic breast cancer: can metastatic breast cancer be cured? J Natl Cancer Inst. 2010 Apr 7;102(7):456-63.

15. Šeparović R, Zorica R, Silovski T, Pavlović M, Vazdar $\mathrm{Lj}$, Pavlica V. Systemic therapy of metastatic breast cancer. Libri oncologici. 2014;42:51-60.

Sažetak

\section{RIJEDAK SLUČAJ METASTAZE INVAZIVNOG LOBULARNOG KARCINOMA DOJKE U ENDOMETRIJ}

\section{Danolić, L. Marcelić, I. Alvir, I. Mamić, L. Šušnjar, Z. Rendić-Miočević i M. Puljiz}

Metastaze u ženski spolni sustav ekstragenitalnih primarnih karcinoma su rijetke te su najčešće znak uznapredovale bolesti. Lobularni histološki tip karcinoma dojke je najčešće primarno sijelo metastaza u ženski spolni sustav. U radu je prikazan rijedak slučaj 55- godišnje bolesnice s endometralnom metastazom karcinoma dojke koja se prvotno prezentirala sa simptomima vaginalnog krvarenja u poslijemenopauzi. Istaknuta je važnost biopsije endometrija u postavljanju točne dijagnoze i razlikovanju primarne od metastatske bolesti endometrija s obzirom na činjenicu kako se njihovo liječenje i prognoza u potpunosti razlikuju.

KLJUČNE RIJEČI: rak dojke, metastaza, endometrij, vaginalno krvarenje 